\title{
Gold-catalyzed oxycyclization of allenic carbamates: expeditious synthesis of 1,3-oxazin-2-ones
}

\author{
Benito Alcaide $^{* 1}$, Pedro Almendros ${ }^{*}$, M. Teresa Quirós ${ }^{1}$ \\ and Israel Fernández ${ }^{3}$
}

\section{Full Research Paper}

\section{Address:}

${ }^{1}$ Grupo de Lactamas y Heterociclos Bioactivos, Departamento de Química Orgánica I, Unidad Asociada al CSIC, Facultad de Química, Universidad Complutense de Madrid, 28040-Madrid, Spain, ${ }^{2}$ Instituto de Química Orgánica General (IQOG), Consejo Superior de Investigaciones Científicas (CSIC), Juan de la Cierva 3, 28006-Madrid, Spain and ${ }^{3}$ Departamento de Química Orgánica I, Facultad de Química, Universidad Complutense de Madrid, 28040-Madrid, Spain

\section{Email:}

Benito Alcaide* - alcaideb@quim.ucm.es; Pedro Almendros* palmendros@iqog.csic.es

* Corresponding author

\section{Keywords:}

allenes; computational chemistry; gold; gold catalysis; heterocycles; reaction mechanisms

\section{Open Access}

Beilstein J. Org. Chem. 2013, 9, 818-826.

doi:10.3762/bjoc.9.93

Received: 08 February 2013

Accepted: 26 March 2013

Published: 26 April 2013

This article is part of the Thematic Series "Gold catalysis for organic synthesis II".

Guest Editor: F. D. Toste

(C) 2013 Alcaide et al; licensee Beilstein-Institut.

License and terms: see end of document.

\section{Abstract}

A combined experimental and computational study on regioselective gold-catalyzed synthetic routes to 1,3-oxazinan-2-ones (kinetically controlled products) and 1,3-oxazin-2-one derivatives (thermodynamically favored) from easily accessible allenic carbamates has been carried out.

\section{Introduction}

The search for new synthetic routes to 1,3-oxazin-2-one derivatives [1] is of interest because of the biological activity of these molecules [2-7]. Carretero and colleagues have published the $\mathrm{Au}(\mathrm{I})$-catalyzed cyclization of $N$-Boc-3-butyn-1-amines to afford six-membered 2-oxazinones, namely, 6-methylene-1,3oxazinan-2-ones involving a 6-exo-dig cyclization [1]. This interesting method avoids complicated prefunctionalization of starting materials and minimizes the formation of byproducts; however, it is used just for the preparation of four simple examples. 1,3-Oxazin-2-ones are also used as valuable intermediates in organic synthesis [8-14]. Recently, allenes have attracted much attention as they have been used for the preparation of both biologically relevant drugs as well as advanced materials [15-27]. However, regioselectivity problems are significant (endo-trig versus endo-dig versus exo-dig versus exo-trig cyclization). Great effort is currently being made in the search for a variety of reactions promoted by gold salts due to their impressive catalytic properties [28-41]. The Boc protective group has been widely used in allene chemistry, being an inert and recommended partner in gold- and palladium-catalyzed 
aminocyclizations of allenes [42]. On the other hand, reports of gold-catalyzed cyclizations leading to heterocycles that contain more than one heteroatom are rare [43-48]. Besides, it has been reported very recently that the $\mathrm{Au}(\mathrm{I})$-catalyzed cyclization of a $N$-phenethyl- $N$-Boc-protected allenamide failed [49]. Despite the above precedents, but in continuation of our interest in heterocyclic and allene chemistry [50-55], we decided to examine the gold-catalyzed cyclization of $N$-Boc-allenes with the aim of establishing a protocol for the synthesis of 1,3oxazin-2-one derivatives in which the carbamate group should serve as the source of $\mathrm{CO}_{2}$.

\section{Results and Discussion}

To explore the effects of various substrates on gold-catalyzed oxycyclization reactions, a number of new allenic carbamates were synthesized as shown in Scheme 1. Starting materials, tert-butyl (prop-2-ynyl)carbamates $\mathbf{1 a - j}$, were obtained both in the racemic form and in optically pure form by using standard methodologies. Thus, alkynylcarbamates $\mathbf{1 a}-\mathbf{g}$ were prepared through reductive amination of the appropriate aldehyde with propargylamine, followed by $\mathrm{Boc}_{2} \mathrm{O}$ treatment of the corresponding $\mathrm{N}$-substituted prop-2-yn-1-amine. Alkynylcarbamate 1h was prepared from Garner's aldehyde following a literature report [56,57]. Alkynylcarbamate 1i was readily accessed from $(S)$-prolinol by using a modified known procedure [58]. Alkynylcarbamate $\mathbf{1} \mathbf{j}$ was achieved through the reaction of 3-bromo- $1 H$-indole-2-carbaldehyde with the Ohira-Bestmann reagent followed by the addition of $\mathrm{Boc}_{2} \mathrm{O}$. Terminal alkynes 1 were conveniently converted into allenic carbamates $\mathbf{2}$ by treatment with paraformaldehyde in the presence of diisopropylamine and copper(I) bromide (Crabbé reaction) [59,60].

We employed three different gold salts in our initial screening of catalysts for the model system, allenic carbamate 2a. Initially, the use of $\mathrm{AuCl}_{3}$ and $\mathrm{AuCl}$ were tested, but both failed to catalyze the reaction. Fortunately, we found that $\left[\mathrm{AuClPPh}_{3}\right] /$ AgOTf was an excellent catalyst for our purpose. To our delight, the reaction of allenic carbamate $\mathbf{2} \mathbf{a}$ at room temperature afforded 3-benzyl-6-methylene-1,3-oxazinan-2-one (3a) bearing an exocyclic double bond as the sole product (Scheme 2). Adding a catalytic amount of Brønsted acid (PTSA) into the reaction system did slightly improve the yield of 3a. Solvent screening demonstrated that dichloromethane was the best choice in the reaction.

As revealed in Scheme 2, a variety of allenic carbamates $\mathbf{2}$ were also suitable for such heterocyclization reactions to afford 1,3oxazinan-2-ones 3. To increase the molecular diversity by incorporating more 1,3-oxazin-2-ones in the molecule, compound $\mathbf{2 g}$ having two allenic carbamate units was used. Notably, bis(allenic carbamate) $\mathbf{2 g}$ also undergoes this interest- ing transformation to give bis(6-methylene-1,3-oxazinan-2-one) 3g through a two-fold cyclization. This product particularly underlines the power of the present cyclization reaction, as none of the conventional methods would allow its synthesis with such great ease.

Interestingly, as a first try, we were pleased to notice that the reaction of allenyl derivative $2 \mathbf{a}$ in dichloromethane at $90{ }^{\circ} \mathrm{C}$, afforded 1,3-oxazin-2-one 4a bearing an endocyclic double bond as the major component, and 1,3-oxazinan-2-one 3a was also isolated as a minor component. Notably, starting from allenic carbamates $\mathbf{2} \mathbf{a}-\mathbf{j}$ and performing the reaction in dichloromethane at $130{ }^{\circ} \mathrm{C}$, a series of 6-methyl-3-substituted 3,4-dihydro-2H-1,3-oxazin-2-ones $\mathbf{4 a - j}$ were exclusively formed (Scheme 2) [61-68]. The observed regioselectivity is worthy of note, because under our reaction conditions only $1,3-$ oxazinan-2-ones 3 (arising from 6-endo-dig cyclization) or 3,4dihydro- $2 H$-1,3-oxazin-2-ones 4 (arising from 6-exo-dig cyclization) were achieved, with the nucleophilic oxygen attacking the central allene carbon atom in each case. This is an interesting result, because the available examples on related metal-catalyzed allene heterocyclizations usually lead to 5-exotrig cyclization [69,70]; only Hashmi et al. have recently reported an attack at the central position of the allene in allenylamides [44].

Thus, it is possible to suppress the formation of the 1,3-oxazinan-2-one ring by performing the reaction at higher temperature, yielding the 1,3-oxazin-2-one as the exclusive product. A general trend can be deduced on the basis of these results: heterocycle 4 is the thermodynamically controlled product while heterocycle 3 is the kinetically controlled product [7173]. Probably, double-bond migration in compounds 3 results in the formation of the 1,3-oxazin-2-one 4 . In order to verify the role of the $\mathrm{Au}(\mathrm{I})$ catalyst in the double-bond migration process, we set up two experiments. Heating a mixture of 3a with $\mathrm{Au}(\mathrm{OTf}) \mathrm{PPh}_{3}$ at a loading of $2.5 \mathrm{~mol} \%$ in dichloromethane for $1.5 \mathrm{~h}$ at $130{ }^{\circ} \mathrm{C}$ resulted in full conversion into 4a. Running the same reaction in the absence of any catalyst resulted in $30 \%$ conversion after two days, as determined by ${ }^{1} \mathrm{H}$ NMR. Treatment of 1,3-oxazinan-2-one 3a with $5 \mathrm{~mol} \% \mathrm{TfOH}$ in $\mathrm{CH}_{2} \mathrm{Cl}_{2}$ at room temperature did not proceed to give an appreciable amount of 3,4-dihydro-2H-1,3-oxazin-2-one 4a after $2 \mathrm{~h}$. This indicates that the $\mathrm{Au}(\mathrm{I})$ catalyst might participate in the doublebond migration process; being a possible intermediate, the $\pi$-allyl complex 5 is depicted in Scheme 3 [74]. Despite that, the isomerization process can be also viewed as an intramolecular 1,3-H shift assisted by gold.

A possible pathway for the gold-catalyzed achievement of heterocycles $\mathbf{3}$ from allenyl-tethered carbamates $\mathbf{2}$ may initially 


\begin{tabular}{|c|c|c|c|c|}
\hline & $\stackrel{\mathrm{i}-\mathrm{iii})}{\longrightarrow}$ & & iv) & R N N N \\
\hline & & $\begin{array}{l}\text { 1a } R=P h(51 \%) \\
\text { 1b } R=P M P(71 \%)\end{array}$ & & $\begin{array}{l}\text { 2a R }=\operatorname{Ph}(57 \%) \\
\text { 2b }=P M P(89 \%)\end{array}$ \\
\hline
\end{tabular}<smiles>CC1(C)OCC(C=O)O1</smiles>

$\stackrel{\text { i-iii) }}{\longrightarrow}$<smiles>C#CCN(CC1COC(C)(C)O1)C(=O)O</smiles>

$(+)-1 \mathrm{c}(77 \%)$<smiles>[R20]C1C(=O)N([R1])C1CO</smiles><smiles>O=Cc1ccc(C=O)cc1</smiles>

$\stackrel{\mathrm{i}-\mathrm{iii})}{\longrightarrow}$<smiles>CC1(C)OCC(C=O)N1C(=O)O</smiles><smiles>C1=CC=C1</smiles><smiles>OCC1CCCN1</smiles>
$\underset{\text { v) }}{\stackrel{\text { vi), vii) }}{\longrightarrow}}$<smiles>O=Cc1[nH]c2ccccc2c1Br</smiles><smiles>COP(=O)(OC)C(=N)C(C)=O</smiles>

Ohira-Bestmann reagent<smiles>C#CCN(CC#C)Cc1ccc(C(=O)OCc2ccccc2)cc1</smiles>

1g (38\%)<smiles>C#CC1COC(C)(C)N1C(=O)c1ccccc1</smiles>

(-)-1h (71\%)<smiles>C#CC1CCCN1C(=O)OC(C)(C)C</smiles>

(-)-1i (66\%)<smiles>C#Cc1c(Br)c2ccccc2n1C(=O)OC(C)(C)C</smiles>

1j (54\%)

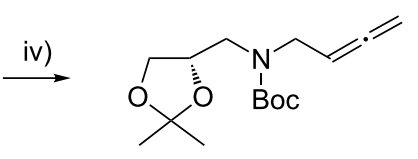

$(+)-2 c(69 \%)$

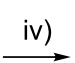<smiles>[R10]C1C(=O)N([R16])C1CN(CC)CC=C</smiles>

$(+)-1 d R^{1}=$ Me, $R^{2}=\operatorname{PMP}(57 \%)$
$(+)-1 e R^{1}=$ Me, $R^{2}=\operatorname{Bn}(60 \%)$
$(+)-1 f R^{1}=$ methallyl, $R^{2}=$ PMP (72\%)

(+)-2d (81\%)

$(+)-2 \mathbf{e}(71 \%)$

$(+)-2 f(64 \%)$

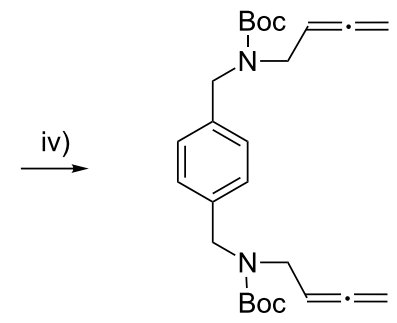

2g (45\%)

$\stackrel{\text { iv) }}{\longrightarrow}$<smiles>C=C=CC1COC(C)(C)N1C(=O)OC(C)(C)C</smiles>

$(-)-2 \mathrm{~h}(62 \%)$

$\stackrel{\text { iv) }}{\longrightarrow}$<smiles>C=C=C[C@@H]1CCCN1C(=O)OC(C)(C)C</smiles>

(-)-2i (79\%)

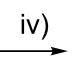

2j $(77 \%)$

Scheme 1: Preparation of allenic carbamates 2a-j. Reagents and conditions: (i) Propargylamine, $\mathrm{MgSO}_{4}, \mathrm{CH}_{2} \mathrm{Cl}_{2}, \mathrm{rt}, 15 \mathrm{~h}$. (ii) $\mathrm{NaBH}_{4}, \mathrm{MeOH} \mathrm{rt}$, 0.5 h. (iii) $\mathrm{Boc}_{2} \mathrm{O}, \mathrm{Et}_{3} \mathrm{~N}, \mathrm{CH}_{2} \mathrm{Cl}_{2}$, rt, 2-15 h. (iv) $\left(\mathrm{CH}_{2} \mathrm{O}\right)_{n}, \mathrm{iPr}_{2} \mathrm{NH}, \mathrm{CuBr}, 1,4-$ dioxane, reflux, $1 \mathrm{~h}$. (v) Ohira-Bestmann reagent, $\mathrm{K}_{2} \mathrm{CO}_{3}, \mathrm{MeOH}$, rt, $15 \mathrm{~h}$. (vi) $\mathrm{Boc}_{2} \mathrm{O}$, DMAP, $\mathrm{CH}_{3} \mathrm{CN}$, rt, $2 \mathrm{~h}$. (vii) Dess-Martin periodinane, $\mathrm{CH}_{2} \mathrm{Cl}_{2}$, rt. $\mathrm{PMP}=4-\mathrm{MeOC}_{6} \mathrm{H}_{4}$. 

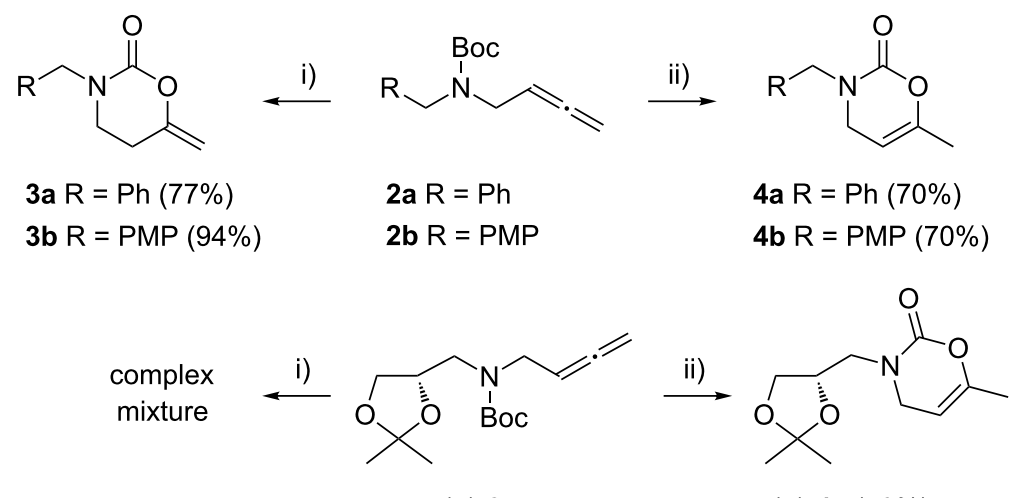

$(+)-2 c$

$(+)-4 c(70 \%)$<smiles>[R10]O[C@H]1C(=O)N([R2])[C@@H]1CN1CCC(=CC(=C)C)OC1=O</smiles>
(+)-3d (64\%)
$(+)-2 d R^{1}=M e, R^{2}=$ PMP
$(+)-4 d(57 \%)$
$(+)-3 e(70 \%)$
$(+)-2 e R^{1}=M e, R^{2}=B n$
$(+)-4$ e $(68 \%)$
$(+)-3 f(67 \%)$
(+)-2f $\mathrm{R}^{1}=$ methallyl, $\mathrm{R}^{2}=\mathrm{PMP}$
$(+)-4 f(66 \%)$<smiles>C=C=CCN(Cc1ccc(CN(CC=C=C)C(=O)OC(=O)c2ccccc2)cc1)C(=O)OC(=O)C=C=C</smiles>

$3 g(50 \%)$

$2 \mathrm{~g}$

$4 g(54 \%)$

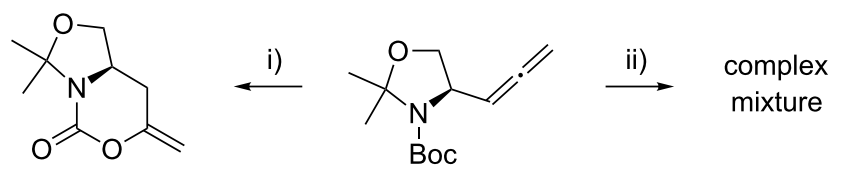

$(-)-3 h(52 \%) \quad(-)-2 h$

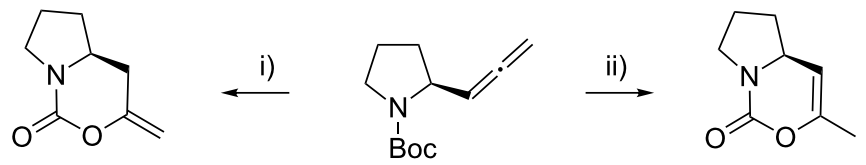
$(-)-3 \mathbf{i}(82 \%)$
$(-)-2 i$
$(-)-4 \mathbf{i}(67 \%)$

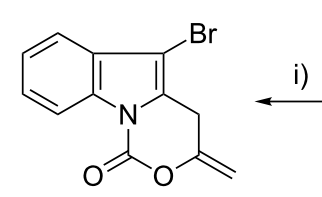

3j (58\%; ratio $3 \mathbf{j}: 4 \mathbf{j}=30: 70)$<smiles>C=C=Cc1c(Br)c2ccccc2n1C(=O)OCc1ccccc1</smiles>

2j<smiles>Cc1cc2c(Br)c3ccccc3n2c(=O)o1</smiles>

4j $(66 \%)$

Scheme 2: Controlled oxycyclization reactions of allenic carbamates 2 to 1,3-oxazinan-2-ones 3 and 1,3-oxazin-2-ones 4 under selective gold-

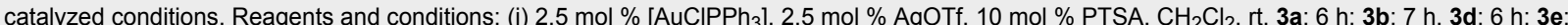

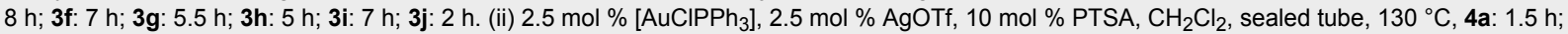

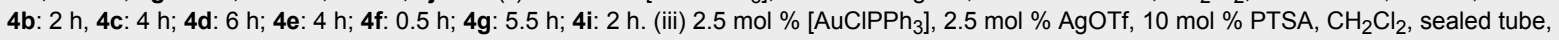
$80^{\circ} \mathrm{C}, 4 \mathrm{j}: 2 \mathrm{~h} . \mathrm{PMP}=4-\mathrm{MeOC}_{6} \mathrm{H}_{4}$. 


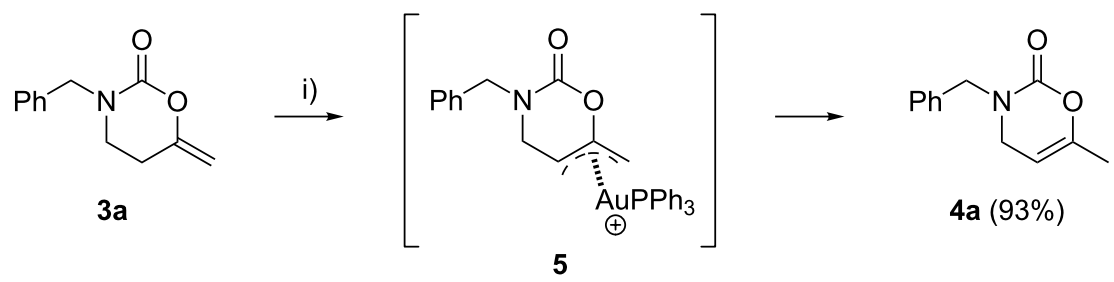

Scheme 3: Possible explanation for the gold-catalyzed isomerization reaction of 1,3-oxazinan-2-one 3a into 1,3-oxazin-2-one 4a. Reagents and conditions: (i) $2.5 \mathrm{~mol} \%$ [AuClPPh 3 ], $2.5 \mathrm{~mol} \% \mathrm{AgOTf}, 10 \mathrm{~mol} \% \mathrm{PTSA}, \mathrm{CH}_{2} \mathrm{Cl}_{2}$, sealed tube, $130{ }^{\circ} \mathrm{C}, 1.5 \mathrm{~h}$.

involve the formation of a complex 6 through coordination of the gold salt to the proximal allenic double bond. Next, chemoand regioselective 6-endo-dig oxyauration of the carbamate carbonyl moiety forms species 7 . Attack of the carbamate carbon$\mathrm{yl}$ group occurs as a result of the stability of the intermediate ammonium cation type 7 . Loss of proton linked to 2-methylprop-1-ene release [75-78], generates neutral species $\mathbf{8}$, which followed by protonolysis of the carbon-gold bond affords 6-methylene-1,3-oxazinan-2-ones 3 with concurrent regeneration of the gold catalyst (Scheme 4, left catalytic cycle). In line with the above mechanistic proposal, the easy breakage of the tert-butyl group at species 7 is essential for the formation of 1,3-oxazinan-2-ones 3 . Besides, the replacement of the tertbutyl group in allenic carbamates 2 by other alkyl functions, such as methyl, did not allow the preparation of heterocycles 3 . In addition to the double-bond isomerization that transforms products 3 into the thermodynamically more favored compounds 4 , a mechanistic scenario involving the initial coordination of the gold to the distal allenic double bond leading to complex 9 , followed by a 6-exo-dig oxyauration is likely for the achievement of 1,3-oxazin-2-ones $\mathbf{4}$ from allenic carbamates $\mathbf{2}$ (Scheme 4, right-hand catalytic cycle).

Density functional theory (DFT) calculations (see Supporting Information File 1) have been carried out at the PCM-M06/ def2-SVP//B3LYP/def2-SVP level to gain more insight into the reaction mechanism of the above discussed gold-catalyzed divergent oxycyclization reaction. The corresponding computed reaction profiles of the model allene $\mathbf{1 M}$ with the model gold catalyst $\mathrm{AuPMe}_{3}$ (OTf) are shown in Figure 1, which gathers the respective free energies (computed at $298 \mathrm{~K}$ ) in $\mathrm{CH}_{2} \mathrm{Cl}_{2}$ solution.

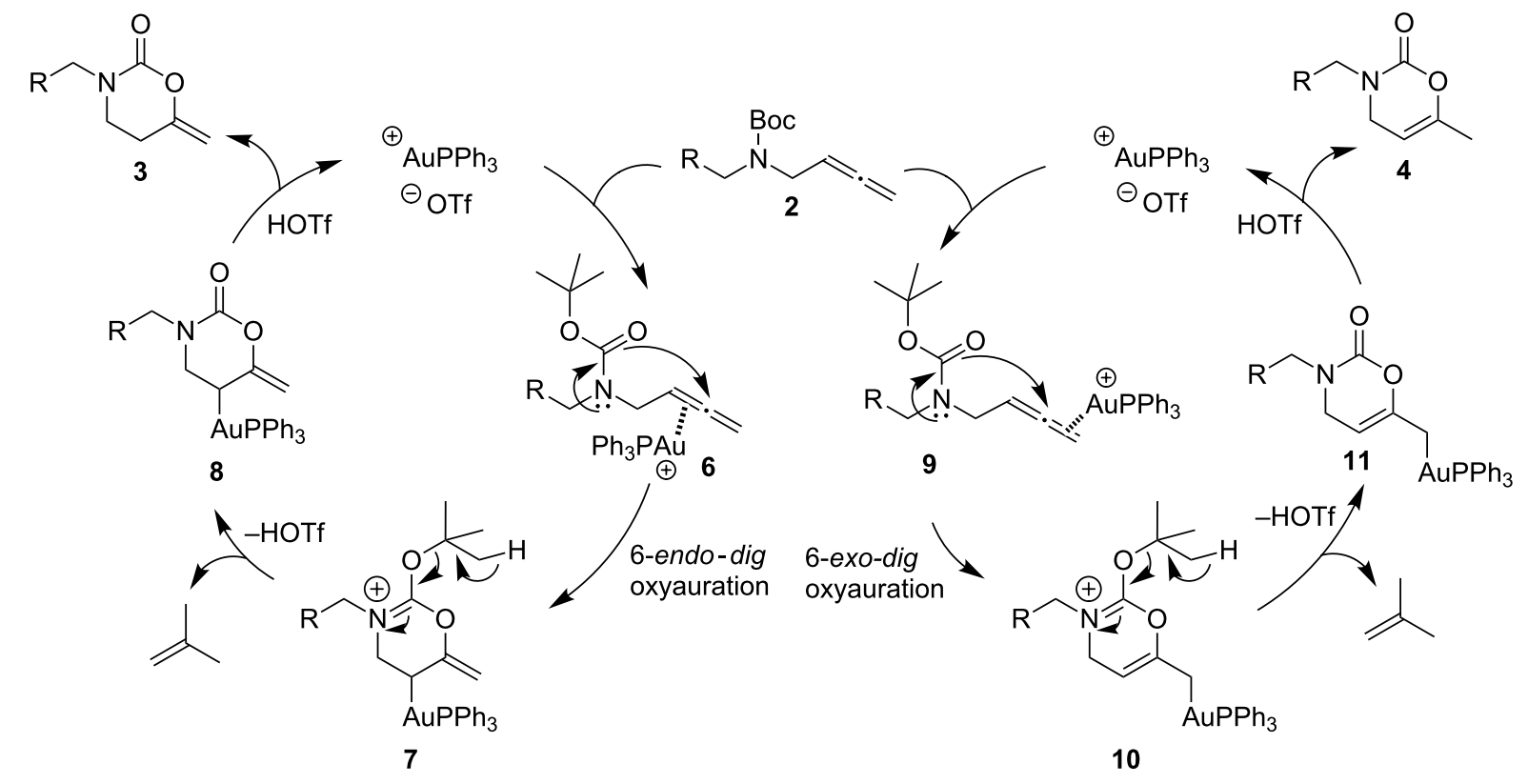

Scheme 4: Mechanistic explanation for the gold-catalyzed oxycyclization reactions of allenic carbamates 2 into 6-methylene-1,3-oxazinan-2-ones 3 or into 3-substituted-3,4-dihydro-2H-1,3-oxazin-2-ones 4. 


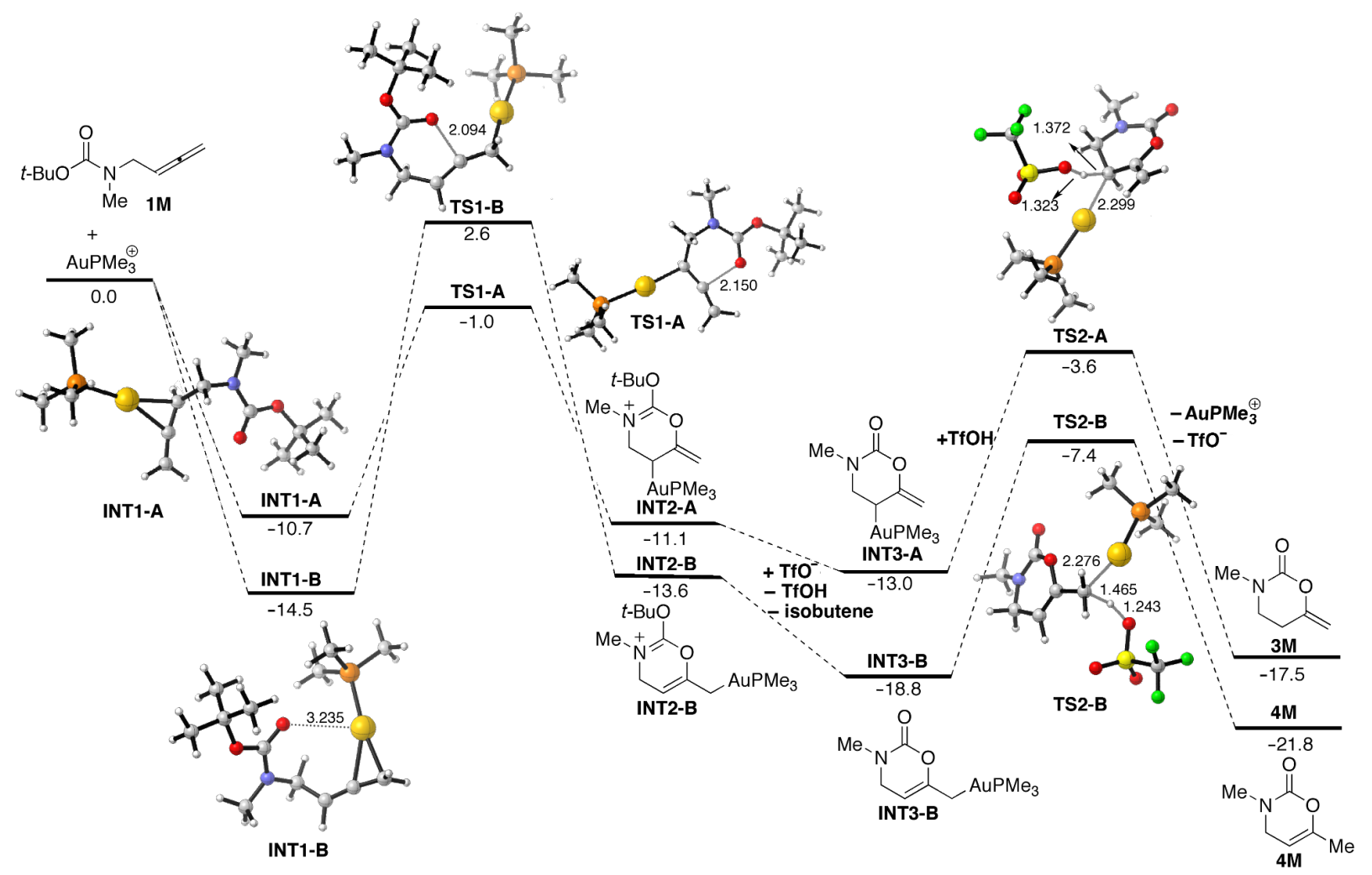

Figure 1: Computed reaction profile for the reaction of $\mathrm{AuPMe}_{3}{ }^{+}$and $1 \mathrm{M}$. Numbers indicate the corresponding PCM-corrected $\Delta \mathrm{G}_{298}$ energies (in $\mathrm{kcal} / \mathrm{mol}$ ) using dichloromethane as solvent. Bond distances are given in angstroms. All data have been computed at the PCM-M06/def2-SVP/I B3LYP/def2-SVP level.

As initially envisaged, two different coordination modes of the metal fragment to the allenic double bond of $\mathbf{1 M}$, i.e., distal versus proximal, are possible. Our calculations indicate that the distal coordination leading to INT1-B is favored over the proximal coordination mode, which forms INT1-A $(\Delta \Delta G=3.8 \mathrm{kcal} /$ $\mathrm{mol}$ ). This is mainly due to the presence of a two-electron stabilizing interaction established by donation of electronic density from the lone pair of the oxygen atom of the carbonyl moiety to a vacant $d$ atomic orbital of the gold atom in INT1-B [79]. Both complexes can undergo the corresponding oxyauration cyclization reaction. Thus, INT1-A is converted into INT2-A in a slightly exergonic process $\left(\Delta G_{\mathrm{R}, 298}=-0.4 \mathrm{kcal} / \mathrm{mol}\right)$ through the saddle point TS1-A, which is associated with the 6-endo-dig cyclization. Similarly, INT1-B is transformed into INT2-B in a slightly endergonic process $\left(\Delta G_{\mathrm{R}, 298}=+0.9 \mathrm{kcal} / \mathrm{mol}\right) \mathrm{via}$ TS1-B, associated with the 6-exo-dig cyclization reaction.

From the data in Figure 1, it becomes obvious that the 6-endodig transformation is kinetically favored over the 6-exo-dig reaction in view of the computed lower activation barrier of the former process $\left(\Delta \Delta G^{\neq}{ }_{298}=+7.4 \mathrm{kcal} / \mathrm{mol}\right)$. However, the cyclic reaction product INT2-B is thermodynamically more stable than the counterpart INT2-A $(\Delta \Delta G=2.5 \mathrm{kcal} / \mathrm{mol})$, which is in agreement with the experimental findings (see above). The next step of the process involves the $\mathrm{TfO}^{-}$promoted elimination of isobutene to form the corresponding INT3 complexes. The driving force of this process is clearly related to the thermodynamically favored release of isobutene $\left(\Delta G_{\mathrm{R}, 298}=-1.9\right.$ and $-5.2 \mathrm{kcal} / \mathrm{mol}$ from INT3-A and INT3-B, respectively). Finally, the protonolysis reaction of the carbon-gold bond by TfOH renders the final products $\mathbf{3} \mathbf{M}$ and $\mathbf{4 M}$ regenerating the catalyst. This step occurs through the transition states TS2-A and TS2-B, respectively, in an exergonic transformation $\left(\Delta G_{\mathrm{R}, 298}=-4.5\right.$ and $-3.0 \mathrm{kcal} / \mathrm{mol}$ from INT3-A and INT3-B, respectively). Again, the data in Figure 1 indicate that the final product $\mathbf{4 M}$ is thermodynamically more stable than $\mathbf{3 M}$, which is in line with the experimentally observed conversion of $\mathbf{3 a}$ into $\mathbf{4} \mathbf{a}$ by heating in the presence and also in the absence of the gold-catalyst. From the computed reaction profile, it can be concluded that the observed divergent cyclization finds its origin in the initial 6-endo versus 6-exo oxyauration reaction steps, with the former being kinetically favored whereas the 
latter is thermodynamically favored. At this point, it cannot be safely discarded that the formation of the thermodynamically more stable 6-exo-dig products is the result of the simple thermally promoted isomerization of the less stable 6-endo-dig species.

\section{Conclusion}

In conclusion, efficient gold-catalyzed synthetic routes to $1,3-$ oxazinan-2-one and 1,3-oxazin-2-one derivatives from easily accessible allenic carbamates under mild conditions have been reported. The oxycyclization reactions were found to proceed with complete control of regioselectivity. The mechanism of these processes has additionally been investigated by a computational study showing that heterocycles $\mathbf{3}$ are the kinetically controlled products whereas heterocycles 4 are thermodynamically favored.

\section{Experimental}

\section{General Information}

${ }^{1} \mathrm{H}$ NMR and ${ }^{13} \mathrm{C}$ NMR spectra were recorded on 700,500 , 300 , or $200 \mathrm{MHz}$ spectrometers. NMR spectra were recorded in $\mathrm{CDCl}_{3}$ solutions, except were otherwise stated. Chemical shifts are given in parts per million relative to TMS $\left({ }^{1} \mathrm{H}, 0.0 \mathrm{ppm}\right)$ or $\mathrm{CDCl}_{3}\left({ }^{13} \mathrm{C}, 76.9 \mathrm{ppm}\right)$. Low- and high-resolution mass spectra were taken on a QTOF LC-MS spectrometer using the electronic impact (EI) or electrospray modes (ES) unless otherwise stated. Specific rotation $[\alpha]_{\mathrm{D}}$ is given in $10^{-1} \mathrm{deg} \mathrm{cm}^{2} \mathrm{~g}^{-1}$ at $20{ }^{\circ} \mathrm{C}$, and the concentration $(c)$ is expressed in grams per $100 \mathrm{~mL}$. All commercially available compounds were used without further purification.

\section{Typical procedure for the $\mathrm{Au}(\mathrm{I})$-catalyzed preparation of 1,3-oxazin-2-ones, 4}

$\left[\mathrm{AuClPPh}_{3}\right](0.00475 \mathrm{mmol}), \mathrm{AgOTf}(0.00475 \mathrm{mmol})$, and $p$-toluenesulfonic acid $(0.019 \mathrm{mmol})$ were sequentially added to a stirred solution of the allenic carbamate 2 a $(50 \mathrm{mg}$, $0.19 \mathrm{mmol})$ in dichloromethane $(1.9 \mathrm{~mL})$. The resulting mixture was heated in a sealed tube at $130{ }^{\circ} \mathrm{C}$ until disappearance of the starting material (TLC, $1.5 \mathrm{~h}$ ). The reaction was allowed to cool to room temperature and filtered through a pack of celite. The filtrate was extracted with dichloromethane $(3 \times 5 \mathrm{~mL})$, and the combined extracts were washed twice with brine. The organic layer was dried $\left(\mathrm{MgSO}_{4}\right)$, concentrated under reduced pressure, and purified by flash column chromatography on silica gel (hexanes/ethyl acetate 4:1) to afford product 4a (27 mg, 70\%) as a colorless oil. ${ }^{1} \mathrm{H}$ NMR $\left(300 \mathrm{MHz}, \mathrm{CDCl}_{3}\right.$, $\left.25^{\circ} \mathrm{C}\right) \delta 7.33(\mathrm{~m}, 2 \mathrm{H}), 4.76(\mathrm{~m}, 1 \mathrm{H}), 4.58(\mathrm{~s}, 2 \mathrm{H}), 3.68(\mathrm{dq}, J=$ $3.2,1.9 \mathrm{~Hz}, 2 \mathrm{H}), 1.86(\mathrm{td}, J=1.9,1.2 \mathrm{~Hz}, 3 \mathrm{H}) ;{ }^{13} \mathrm{C}$ NMR $(75$ $\left.\mathrm{MHz}, \mathrm{CDCl}_{3}, 2{ }^{\circ} \mathrm{C}\right) \delta 150.9,148.1,135.6,128.7,128.2,127.9$, 94.4, 52.1, 44.6, 18.3; IR $\left(\mathrm{CHCl}_{3}\right)$ v: $1685 \mathrm{~cm}^{-1}$; HRMS-ES $(\mathrm{m} / \mathrm{z})$ : $[\mathrm{M}]^{+}$calcd for $\mathrm{C}_{12} \mathrm{H}_{13} \mathrm{NO}_{2}, 203.0946$; found, 203.0952.

\section{Supporting Information}

\section{Supporting Information File 1}

Experimental details, analytical data of new compounds, copies of ${ }^{1} \mathrm{H}$ NMR and ${ }^{13} \mathrm{C}$ NMR spectra and computational details.

[http://www.beilstein-journals.org/bjoc/content/ supplementary/1860-5397-9-93-S1.pdf]

\section{Acknowledgements}

Financial support from the MINECO [Projects CTQ201233664-C02-01, CTQ2012-33664-C02-02, CTQ2010-20714C02-01, and Consolider-Ingenio 2010 (CSD2007-00006)] and Comunidad Autónoma de Madrid (Projects S2009/PPQ-1752 and S2009/PPQ-1634) are gratefully acknowledged. M. T. Q. thanks MEC for a predoctoral grant.

\section{References}

1. Robles-Machín, R.; Adrio, J.; Carretero, J. C. J. Org. Chem. 2006, 71, 5023. doi:10.1021/jo060520y

See for the synthesis of oxazinones from N-Boc-(3-butyn)-1-amines.

2. Eichner, S.; Knobloch, T.; Floss, H. G.; Fohrer, J.; Harmrolfs, K.; Hermane, J.; Schulz, A.; Sasse, F.; Spiteller, P.; Taft, F.; Kirschning, A. Angew. Chem., Int. Ed. 2012, 51, 752. doi:10.1002/anie.201106249

3. Wolfe, A. L.; Duncan, K. K.; Parelkar, N. K.; Weir, S. J.; Vielhauer, G. A.; Boger, D. L. J. Med. Chem. 2012, 55, 5878. doi:10.1021/jm300330b

4. Taft, F.; Harmrolfs, K.; Nickeleit, I.; Heutling, A.; Kiene, M.; Malek, N.; Sasse, F.; Kirschning, A. Chem.-Eur. J. 2012, 18, 880. doi:10.1002/chem.201101640

5. Chinkov, N.; Warm, A.; Carreira, E. M. Angew. Chem., Int. Ed. 2011, 50, 2957. doi:10.1002/anie.201006689

6. Fishkin, N.; Maloney, E. K.; Chari, R. V. J.; Singh, R. Chem. Commun. 2011, 47, 10752. doi:10.1039/c1cc14164c

7. Zhang, F.; Qian, L.; Flood, P. M.; Shi, J.-S.; Hong, J.-S.; Gao, H.-M. J. Pharmacol. Exp. Ther. 2010, 333, 822. doi:10.1124/jpet.110.165829

8. Richter, H.; Fröhlich, R.; Daniliuc, C.-G.; García-Mancheño, O. Angew. Chem., Int. Ed. 2012, 51, 8656. doi:10.1002/anie.201202379

9. Kuznetsov, N. Yu.; Maleev, V. I.; Khrustalev, V. N.; Mkrtchyan, A. F.; Godovikov, I. A.; Strelkova, T. V.; Bubnov, Y. N. Eur. J. Org. Chem. 2012, 334. doi:10.1002/ejoc.201101114

10. Shpak-Kraievskyi, P.; Yin, B.; Martel, A.; Dhal, R.; Dujardin, G.; Laurent, M. Y. Tetrahedron 2012, 68, 2179. doi:10.1016/j.tet.2012.01.002

11. Tian, C.; Jiao, X.; Liu, X.; Li, R.; Dong, L.; Liu, X.; Zhang, Z.; Xu, J.; Xu, M.; Xie, P. Tetrahedron Lett. 2012, 53, 4892. doi:10.1016/j.tetlet.2012.07.011

12. Zhou, H.-B.; Lee, J. H.; Mayne, C. G.; Carlson, K. E.; Katzenellenbogen, J. A. J. Med. Chem. 2010, 53, 3349. doi:10.1021/jm100052k

13. Sato, S.; Shibuya, M.; Kanoh, N.; Iwabuchi, Y. Chem. Commun. 2009, 6264. doi:10.1039/b913770j

14. Osa, Y.; Hikima, Y.; Sato, Y.; Takino, K.; Ida, Y.; Hirono, S.; Nagase, H. J. Org. Chem. 2005, 70, 5737. doi:10.1021/jo0501644 
15. Yu, S.; Ma, S. Angew. Chem., Int. Ed. 2012, 51, 3074. doi:10.1002/anie.201101460

16. Rivera-Fuentes, P.; Diederich, F. Angew. Chem., Int. Ed. 2012, 51, 2818. doi:10.1002/anie.201108001

17. Krause, N.; Winter, C. Chem. Rev. 2011, 111, 1994. doi:10.1021/cr1004088

18. Alcaide, B.; Almendros, P. Chem. Rec. 2011, 11, 311. doi:10.1002/tcr.201100011

19. Alcaide, B.; Almendros, P.; Aragoncillo, C. Chem. Soc. Rev. 2010, 39 , 783. doi:10.1039/b913749a

20. Brasholz, M.; Reissig, H.-U.; Zimmer, R. Acc. Chem. Res. 2009, 42, 45. doi:10.1021/ar800011h

21. Krause, N., Ed. Compounds with all carbon functions: Cumulenes and Allenes; Science of Synthesis; Georg Thieme: Stuttgart, Germany, 2007; Vol. 44.

22. Ma, S. Chem. Rev. 2005, 105, 2829. doi:10.1021/cr020024j

23. Krause, N.; Hashmi, A. S. K., Eds. Modern Allene Chemistry; Wiley-VCH: Weinheim, Germany, 2004.

24. Alcaide, B.; Almendros, P. Eur. J. Org. Chem. 2004, 3377. doi:10.1002/ejoc.200400023

25. Bates, R. W.; Satcharoen, V. Chem. Soc. Rev. 2002, 31, 12. doi:10.1039/b103904k

26. Zimmer, R.; Dinesh, C. U.; Nandanan, E.; Khan, F. A. Chem. Rev. 2000, 100, 3067. doi:10.1021/cr9902796

27. Hashmi, A. S. K. Angew. Chem., Int. Ed. 2000, 39, 3590 doi:10.1002/1521-3773(20001016)39:20<3590::AID-ANIE3590>3.0.CO ;2-L

28. Hashmi, A. S. K.; Toste, F. D., Eds. Modern Gold Catalyzed Synthesis; Wiley-VCH: Weinheim, Germany, 2012.

29. Rudolph, M.; Hashmi, A. S. K. Chem. Soc. Rev. 2012, 41, 2448. doi:10.1039/c1cs15279c

30. Corma, A.; Leyva-Pérez, A.; Sabater, M. J. Chem. Rev. 2011, 111, 1657. doi:10.1021/cr100414u

31. Rudolph, M.; Hashmi, A. S. K. Chem. Commun. 2011, 47, 6536. doi:10.1039/c1cc10780a

32. Alcaide, B.; Almendros, P.; Alonso, J. M. Org. Biomol. Chem. 2011, 9, 4405. doi:10.1039/c1ob05249g

33. Bandini, M. Chem. Soc. Rev. 2011, 40, 1358. doi:10.1039/c0cs00041h

34. Hashmi, A. S. K. Angew. Chem., Int. Ed. 2010, 49, 5232. doi:10.1002/anie.200907078

35. Lipshutz, B.; Yamamoto, Y., Eds. Coinage Metals in Organic Synthesis. Chem. Rev. 2008, 108, 2793-3442.

36. Hutchings, G. J.; Brust, M.; Schmidbaur, H., Eds. Gold - Chemistry, Materials and Catalysis. Chem. Soc. Rev. 2008, 37, 1745-2140.

37. Muzart, J. Tetrahedron 2008, 64, 5815. doi:10.1016/j.tet.2008.04.018

38. Hashmi, A. S. K. Chem. Rev. 2007, 107, 3180. doi:10.1021/cr000436x

39. Jiménez-Núñez, E.; Echavarren, A. M. Chem. Commun. 2007, 333 doi:10.1039/b612008c

40. Hashmi, A. S. K.; Hutchings, G. J. Angew. Chem., Int. Ed. 2006, 45, 7896. doi:10.1002/anie.200602454

41. Zhang, L.; Sun, J.; Kozmin, S. A. Adv. Synth. Catal. 2006, 348, 2271. doi:10.1002/adsc. 200600368 See for a review.

42. Alcaide, B.; Almendros, P. Adv. Synth. Catal. 2011, 353, 2561. doi:10.1002/adsc.201100160

43. Higginbotham, M. C. M.; Bebbington, M. W. P. Chem. Commun. 2012, 48, 7565. doi:10.1039/c2cc33711h

44. Hashmi, A. S. K.; Schuster, A. M.; Litters, S.; Rominger, F.; Pernpointner, M. Chem.-Eur. J. 2011, 17, 5661. doi:10.1002/chem.201100132
45. LaLonde, R. L.; Wang, Z. J.; Mba, M.; Lackner, A. D.; Toste, F. D. Angew. Chem., Int. Ed. 2010, 49, 598. doi:10.1002/anie.200905000

46. Li, H.; Widenhoefer, R. A. Org. Lett. 2009, 11, 2671. doi:10.1021/ol900730w

47. Winter, C.; Krause, N. Angew. Chem., Int. Ed. 2009, 48, 6339. doi:10.1002/anie.200902355

48. Yeom, H.-S.; Lee, E.-S.; Shin, S. Synlett 2007, 2292. doi:10.1055/s-2007-985571

49. Singh, S.; Elsegood, M. R. J.; Kimber, M. C. Synlett 2012, 565. doi:10.1055/s-0031-1290335

50. Alcaide, B.; Almendros, P.; Quirós, M. T.; López, R.; Menéndez, M. I.; Sochacka-Ćwikła, A. J. Am. Chem. Soc. 2013, 135, 898. doi:10.1021/ja3108966

51. Alcaide, B.; Almendros, P.; Cembellín, S.; Martínez del Campo, T.; Fernández, I. Chem. Commun. 2013, 49, 1282. doi:10.1039/c2cc37872h

52. Alcaide, B.; Almendros, P.; Alonso, J. M.; Fernández, I. Chem. Commun. 2012, 48, 6604. doi:10.1039/c2cc32015k

53. Alcaide, B.; Almendros, P.; Aragoncillo, C.; Gómez-Campillos, G.; Arnó, M.; Domingo, L. R. ChemPlusChem 2012, 77, 563. doi:10.1002/cplu.201200090

54. Alcaide, B.; Almendros, P.; Alonso, J. M.; Quirós, M. T.; Gadziński, P. Adv. Synth. Catal. 2011, 353, 1871. doi:10.1002/adsc.201100209

55. Alcaide, B.; Almendros, P.; Carrascosa, R. Chem.-Eur. J. 2011, 17, 4968. doi:10.1002/chem.201100139

56. Bélanger, D.; Tong, X.; Soumaré, S.; Dory, Y. L.; Zhao, Y. Chem.-Eur. J. 2009, 15, 4428. doi:10.1002/chem.200802337

57. Spangenberg, T.; Schoenfelder, A.; Breit, B.; Mann, A. Eur. J. Org. Chem. 2010, 6005. doi:10.1002/ejoc.201000865

58. Paul, A.; Bittermann, H.; Gmeiner, P. Tetrahedron 2006, 62, 8919. doi:10.1016/j.tet.2006.07.007

We used the Dess-Martin oxidation and the Ohira-Bestmann reagent instead of the reported Swern oxidation and Corey-Fuchs olefination.

59. Crabbé, P.; Fillion, H.; André, D.; Luche, J.-L. J. Chem. Soc., Chem. Commun. 1979, 859. doi:10.1039/C39790000859

60. Kuang, J.; Ma, S. J. Org. Chem. 2009, 74, 1763. doi:10.1021/j0802391x

61. Decker, M. Curr. Med. Chem. 2011, 18, 1464. doi:10.2174/092986711795328355

Compounds $\mathbf{3} \mathbf{d}-\mathbf{f}$ and $\mathbf{4} \mathbf{d}-\mathbf{f}$ can be considered as hybrid scaffolds, i.e., as a combination of the biologically relevant $\beta$-lactam and oxazinone frameworks. See for a review on hybrid chemical entities.

62. Tsogoeva, S. B. Mini-Rev. Med. Chem. 2010, 10, 773. doi:10.2174/138955710791608280

63. Meunier, B. Acc. Chem. Res. 2008, 41, 69. doi:10.1021/ar7000843

64. Tietze, L. F.; Bell, H. P.; Chandrasekhar, S. Angew. Chem., Int. Ed. 2003, 42, 3996. doi:10.1002/anie.200200553

65. Kochanowska-Karamyan, A. J.; Hamann, M. T. Chem. Rev. 2010, 110, 4489. doi:10.1021/cr900211p

Fused tricyclic 3,4-dihydro-2H-1,3-oxazin-2-one $4 \mathbf{j}$ was more efficiently obtained by performing the reaction at $80^{\circ} \mathrm{C}$. Fused indole derivatives are represented in numerous natural alkaloids and synthetic pharmaceuticals, which display a number of interesting biological activities.

66. Bandini, M.; Eichholzer, A. Angew. Chem., Int. Ed. 2009, 48, 9608. doi:10.1002/anie.200901843

67. Humphrey, G. R.; Kuethe, J. T. Chem. Rev. 2006, 106, 2875. doi:10.1021/cr0505270 
68. Except for fused 6-methylene-1,3-oxazinan-2-one, 3j, heterocycles $\mathbf{3}$ or 4 were exclusively obtained. Surprisingly, the exposure of tert-butyl allenic carbamate $\mathbf{2} \mathbf{j}$ to the gold-catalyzed conditions at room temperature afforded the $\mathbf{1 , 3 - o x a z i n - 2 - o n e ~} \mathbf{4} \mathbf{j}$ as the major adduct, with the corresponding 1,3-oxazinan-2-one adduct $\mathbf{3} \mathbf{j}$ being the minor component.

69. Chen, B.; Wang, N.; Fan, W.; Ma, S. Org. Biomol. Chem. 2012, 10 , 8465. doi:10.1039/c2ob26291f

70. Shu, W.; Yu, Q.; Jia, G.; Ma, S. Chem.-Eur. J. 2011, 17, 4720. doi:10.1002/chem.201003611

71. Lee, P. H.; Kang, D.; Choi, S.; Kim, S. Org. Lett. 2011, 13, 3470. doi:10.1021/ol2012132

72. Mo, J.; Kang, D.; Eom, D.; Kim, S. H.; Lee, P. H. Org. Lett. 2013, 15, 26. doi:10.1021/ol3029274

73. Lee, P. H.; Kim, S.; Kang, D.; Park, A.; Chary, B. C.; Kim, S Angew. Chem., Int. Ed. 2010, 49, 6806. doi:10.1002/anie.201001799

74. Komiya, S.; Ozaki, S. Chem. Lett. 1988, 17, 1431. doi:10.1246/cl.1988.1431 See for the isolation of an allylic gold complex.

75. ${ }^{1} \mathrm{H}$ NMR of the reaction mixtures revealed the presence of 2-methylprop-1-ene, which is likely formed from the tert-butyl fragmentation. For pioneering work on the introduction of tert-butyl carbonates as a cation-trapping group in gold catalysis, see references [76-78].

76. Buzas, A.; Gagosz, F. Org. Lett. 2006, 8, 515. doi:10.1021/ol053100o

77. Kang, J.-E.; Shin, S. Synlett 2006, 717. doi:10.1055/s-2006-933110

78. Shin, S.-H. Bull. Korean Chem. Soc. 2005, 26, 1925. doi:10.5012/bkcs.2005.26.12.1925

79. The corresponding second-order perturbation energy from the NBO method associated with this $\mathrm{LP}(\mathrm{O}) \rightarrow \mathrm{d}(\mathrm{Au})$ delocalization was computed to be ca. $-5 \mathrm{kcal} / \mathrm{mol}$.

\section{License and Terms}

This is an Open Access article under the terms of the Creative Commons Attribution License (http://creativecommons.org/licenses/by/2.0), which permits unrestricted use, distribution, and reproduction in any medium, provided the original work is properly cited.

The license is subject to the Beilstein Journal of Organic Chemistry terms and conditions:

(http://www.beilstein-journals.org/bjoc)

The definitive version of this article is the electronic one which can be found at: doi:10.3762/bjoc. 9.93 